
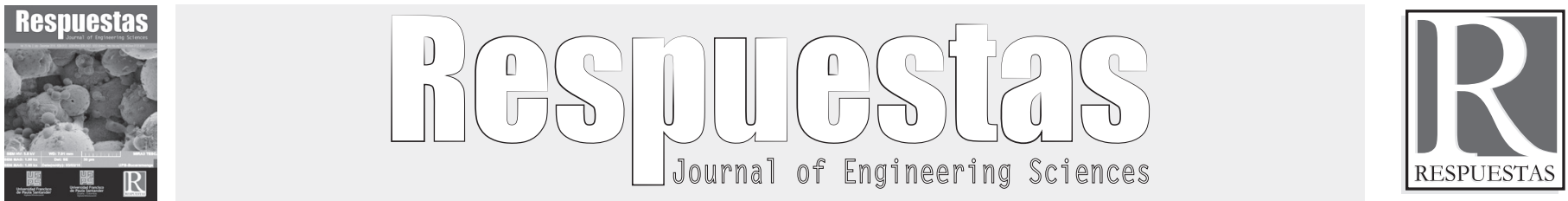

Original Article

https://doi.org/10.22463/0122820X.1739

\title{
Germinated kamut wheat (Triticum turgidum), quinoa (Chenopodium quinoa) and mung bean (Vigna radiata). An alternative for the feeding of colonies of ants Atta cephalotes under laboratory conditions.
}

Germinados de trigo kamut (Triticum turgidum), quinua (Chenopodium quinoa) y frijol mungo (Vigna radiata): Una alternativa para la alimentación de colonias de hormigas Atta cephalotes en condiciones de laboratorio.

Johana Ramírez-Olier ${ }^{1}$, Margarita María Jaramillo-Ciro ${ }^{2 *}$, Beatriz González-Agudelo ${ }^{3}$, Liliana Rocío Botero-Botero

${ }^{1}$ Magíster en Ingeniería Urbana, jpramirez@udem.edu.co, Orcid: 0000-0003-4883-2618, Universidad de Medellín, Medellín, Colombia

2*Magister en Ingeniería Urbana, margarita.jaramillo@usbmed.edu.co, Orcid: 0000-0002-7424-4425, Universidad de San Buenaventura, Medellin, Colombia.

${ }^{3}$ Licenciada en Biología y Química, biotecnologia@udem.edu.co, Orcid: 0000-0003-0626-3808, Universidad de Medellín, Medellín, Colombia.

${ }^{4}$ Doctor en Biología, lbotero@udem.edu.co, Orcid: 0000-0003-0626-3808, Universidad de Medellín, Medellín, Colombia

How to cite: J. Ramírez-Olier, M.M. Jaramillo-Ciro, B. González-Agudelo and L.R. Botero-Botero, "Germinated kamut wheat (Triticum turgidum), quinoa (Chenopodium quinoa) and mung bean (Vigna radiata). An alternative for the feeding of colonies of ants Atta cephalotes under laboratory conditions", Respuestas, vol. 23, no. 2, pp. 62-74, 2018.

Received on January 23, 2018 - Approved on June 06, 2018.

\begin{tabular}{|c|c|}
\hline & ABSTRACT \\
\hline $\begin{array}{l}\text { Keywords: } \\
\text { Atta cephalotes, } \\
\text { colonies, feeding, } \\
\text { germinated, } \\
\text { Triticum turgidum. }\end{array}$ & $\begin{array}{l}\text { The establishment of colonies of Atta cephalotes cutter ants under laboratory conditions has been proposed } \\
\text { for the study and development of plague control products. However, few laboratories in Colombia have } \\
\text { colonies of Atta cephalotes cutter ants, with food being a limiting factor given their sensitivity, selectivity } \\
\text { and voracity. In this study, the use of wheat germinated kamut (Triticum turgidum), quinoa (Chenopodium } \\
\text { quinoa) and mung bean (Vigna radiata) as an alternative for the feeding of colonies under laboratory } \\
\text { conditions y mango leaves like control, using mini-colonies was evaluated. In the study, mung bean sprouts } \\
\text { and kamut wheat were preferred ( } 100 \% \text { load, } 24 \text { hours), compared to quinoa ( } 89 \pm 10 \% \text { load, } 24 \text { hours). } \\
\text { The determination of the effect of the sprouts on the growth rate of the mini-colonies was evaluated during } \\
8 \text { weeks, showing that the germinated kamut wheat and control treatment generated the best growth rates } \\
\text { of fungus in the exponential phase ( } 3.19 \text { and } 3.73 \mathrm{~g} / \text { week respectively) compared with mung beans and } \\
\text { quinoa ( } 1 \mathrm{~g} / \mathrm{wk}) \text {, supporting the potential of kamut wheat for the maintenance of colonies under laboratory } \\
\text { conditions. }\end{array}$ \\
\hline
\end{tabular}

\section{RESUMEN}

Palabras clave:

alimentación, Atta cephalotes, colonias, germinados, Triticum turgidum.
El establecimiento de colonias de hormigas cortadoras Atta cephalotes en condiciones de laboratorio se ha planteado para el estudio y desarrollo de productos de control de plagas. Sin embargo, son pocos los laboratorios en Colombia que poseen colonias de hormigas, siendo su alimentación un factor limitante a causa de su sensibilidad, selectividad y voracidad. En esta investigación, se evaluó la preferencia y potencial alimentario de germinados de trigo kamut (Triticum turgidum), quinua (Chenopodium quinoa) y frijol mungo (Vigna radiata) como alternativa para la alimentación de colonias $A$. cephalotes en condiciones de laboratorio usando mini-colonias y el control. En el estudio los germinados de frijol mungo y el trigo kamut fueron preferidos ( $100 \%$ de carga durante 24 horas), respecto a la quinua ( $89 \pm 10 \%$ de carga durante 24 horas). Los germinados de trigo kamut y el control evidenciaron las mejores velocidades de crecimiento del hongo en la fase exponencial (3.19 y $3.73 \mathrm{~g} /$ sem respectivamente) comparados con frijol mungo y quinua ( $1 \mathrm{~g} / \mathrm{sem})$. El estudio evidencia el potencial del trigo kamut para el mantenimiento de colonias de hormigas A. cephalotes en condiciones de laboratorio. 


\section{Introduction}

Ants of the genus Atta, commonly called mule ants or cutter ants, are exclusive to tropical and subtropical regions distributed from the south of the United States to the north of Argentina. Within their distinctive behaviors it is highlighted that they have the habit of cutting and transporting diverse vegetable fragments to their underground nests for the cultivation of the fungus Leucoagaricus sp., with which they present a symbiotic relationship characterized by a complete mutual dependence in which the ants fulfill their function of cutting plant material and transporting it inside the antbeds and the fungus in turn to grow provides food to the ants [1], [2]. This fungus is the only source of food for the larvae of cutter ants, so ants must cultivate it and generally do it with leaves, flowers and fruits that collect selectively, which have necessary nutrients that allow their proper growth [3], [4]. Cutter ants have been considered as agricultural pests due to their forage activity that causes the destruction of crops, forests and crops of agronomic importance such as yucca (Manihot sculenta), cocoa (Theobroma cacao), coffee (Coffea arabica), maize (Zea mays), cane (Saccharum offinarum), (Citrus sp), mango (Manguifera indiga), as well as forest species of interest such as eucalyptus (Eucaliptus sp) and pine (Pinus patula), causing losses of economic importance that generate the need to apply control strategies with chemically synthesized pesticides, characterized by their high toxicity. However, regulations and new agricultural trends have forced their replacement, generating the need to develop new, less toxic products [1], [2], [5], [6], [7], [8].

Despite the great advantages of having cutter ant colonies under controlled laboratory conditions for the development of new control products, few laboratories have colonies. In the studies the difficulties for the establishment and maintenance of the anthills are evidenced, considering the feeding one of the limiting factors of major importance because of the voracity of the insects[9], [10].

Generally, the diet of ants is composed of leaves and flowers obtained from various plant sources, which is supplemented with flour from different grains, however, the use of leaves and flowers represents an additional risk to the maintenance of the antbeds. The use of systemic insecticides and fungicides is a common practice to control pests and diseases of plants and, generally it is difficult to know the origin of the leaves and flowers used to feed the antbeds, so that at some point the leaves and flowers could be toxic and affect the survival of the colonies in laboratory conditions [9], [10].

Seed sprouts are widely consumed for their nutritional contribution, easy to obtain and manage in the laboratory. With respect to dry grains, sprouts show an increase in enzyme activity and in the availability of amino acids, vitamins and trace minerals that are necessary for growth, immunity and the antioxidant system. These benefits can improve the nutritional potential, also contributing to the control of oxidative stress in animals and generate an additional superior contribution to grains [11], [12].

Within these sprouts are widely known wheat kamut (Triticum turgidum) [13], quinoa (Chenopodium quinoa) [14]-[15] and mung bean (Vigna radiata) [16]-[17], which are gluten-free grains, with a composition and nutritional value such as rice and corn [15], [18].

This study has evaluated the use of wheat kamut (Triticum turgidum), quinoa (Chenopodium quinoa) and mungo bean (Vigna radiata) sprouts in the diet of Atta cephalotes cutter ants in order to facilitate the establishment of colonies under laboratory conditions, thus seeking the development of bioformulates that include plant extracts and entomopathogenic microorganisms and antagonists.

\section{Materials and methods}

The study was divided into 3 stages: a) the preparation of the sprouts, b) the assembly of mini-colonies and c) the evaluation of the potential of the sprouts as a food source.

\section{Preparation of sprouts}

To evaluate the potential use of germinated seeds as a food source, three species were selected: wheat kamut (Triticum turgidum), quinoa (Chenopodium quinoa) and mungo bean (Vigna radiata). For 
germination, the seeds were immersed in water in plastic containers for 8 hours in dark conditions at laboratory room temperature $23 \pm 2^{\circ} \mathrm{C}$. The hydrated seeds were washed 4 times with water for the assembly of the process, the excess was removed and they were kept in a covered container during 3 days, with daily washes. Then, they were transferred to containers with wet filter paper and covered with a porous material to allow aeration, and finally, the seeds were left in a cool place with photoperiod of 12 hours for 4 days to complete 7 days of germination.

\section{Assembly of mini-colonies}

For the assembly of mini-colonies, colonies with more than one year of establishment were selected under laboratory conditions usually fed with mango leaves, with good forage and fungus activity in the chambers of the anthill with a size superior to $20 \mathrm{~cm}$, facilitating with this the survival of those fractions of fungus for the tests. Cleaned and disinfected polypropylene plastic containers $12 \mathrm{~cm}$ wide and 8 $\mathrm{cm}$ high were used, to which a portion of the fungus was deposited with a spatula. Two mini-colonies (test and control) were arranged in each colony.

Each mini-colony consisted of 3 plastic containers used as cameras. One of them was used as a nest, to which a portion of the fungus of the mother colony was deposited with ants of different castes without the queen, the second feeding chamber where the food was arranged and the third chamber as an empty chamber used by the ants to deposit the residues. These mini-colonies remained connected to the mother colony by means of plastic hoses to allow the communication with pheromones between the mini-colonies and the anthill where the queen was.

Finally, the mini-colonies were connected to the mother colony which was separated by a stainless steel mesh to avoid any potential damage to the mother colony from the sprouts. Each study colony was provided with two mini-colonies, experimentation with sprouts and control of common feeding (Figure $1)$.

\section{Sprout evaluation}

Initially, the mini-colonies were left to settle for 8 days before trials began. During this time, they were fed the maintenance diet consisting of young mango leaves and oat flakes. Subsequently, the nest chamber of the mini-colonies (container + fungus + ants) were weighed to determine their growths to determine the initial weight of experimentation before starting the feeding trials with the sprouts. Among the criteria taken into account for the selection of mini-colonies in the trials were: a) The formation of new fungus and $b$ ) The presence of leaf fragments on the fungus as proof of its feeding activity. To achieve uniformity in the evaluation of the sprouts, two mini-colonies were connected to each mother colony selected for the trial: one for the evaluation of the weight gain with the sprouts and the other for the control carried out with the normal food of the mother colony. The trials were carried out in triplicate, allocating 3 colonies (each with two mini-colonies) for each germinated colony. The mini-colonies were fed daily with $2 \mathrm{~g}$ of fresh food, either mango leaves (used as control food) or sprouts, which were deposited in the feeding chambers.

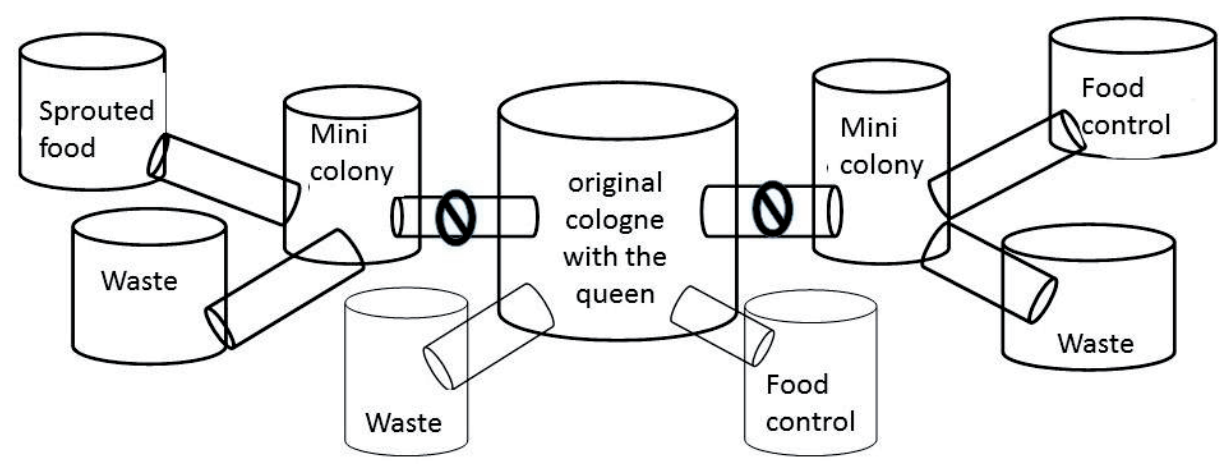

Figure 1. Diagram of the assembly of minicolonies, where to the center is located the original colony with its containers of feeding and elimination of residues and two additional connections blocked in flow that communicate with the used minicolonies to evaluate in one the germinated ones and in the minicolony with food control (tender and fresh leaves of mango). 
Germinated kamut wheat (Triticum turgidum), quinoa (Chenopodium quinoa) and mung bean (Vigna radiata). An alternative for the feeding of colonies of ants Atta cephalotes under laboratory conditions

\section{Determination of ants' preference for sprouts}

Determining the Initial Load: To make an initial quantification of the weight of the sprouts loaded and the preferences of the ants, the initial load was determined. For this purpose, $10 \mathrm{~g}$ of each one of the germinated were placed separately by mini-colony in the feeding chambers during 24 hours, time after which the weighing was carried out to determine the amount of germinated loaded by the ants.

Determination of nutritional potential: In order to determine the nutritional potential of the sprouts, the weight increase of the mini-colonies was determined every 2 weeks for 8 weeks. Daily, the food not used by the ants was removed and replaced by new food. Additionally, in the cases in which the food was exhausted during the day, the same germinated one was added with the same weight, thus allowing the feeding at will.

In order to determine the nutritional potential of the sprouts, the mini-colonies were weighed in weeks 0 , 2, 4, 6 and 8 of the trial, which allowed establishing the growth kinetics for each of the treatments.

Determination of percentage and growth rate: The growth percentage of myicolony was calculated using equation 1 :
The study used a block design with 3 repetitions for each of the treatments.

\section{Results and discussion}

\section{Determination of ants'preference for sprouts}

In this study, all the sprouts were loaded by the ants, evidencing that the three sprouts, mung bean, kamut wheat and quinoa, can be included in the nutritional diet of the mule ants Atta cephalotes. When analyzing the quantities of germinated loaded, it was evidenced the preference by the bean mungo and the wheat kamut, which reached the quantities of load of $10 \mathrm{~g}$ as well as the control. The preference for quinoa was lower with values of $8.9 \pm 0.2 \mathrm{~g}$, evidencing a level of control of the ants of the mini-colonies on the ingestion of this germinated one. In the study the statistical analysis did not find significant differences between the preferences for mung bean, kamut wheat and the control, but between the quinoa germination $(\mathrm{P}<0,002)$. The causes of food preferences can be generated for multiple reasons; in the case of mung bean and kamut wheat sprouts, the amount of water can generate an additional element of preference, facilitating cutting and favoring hydration and access to nutrients by placing them in values similar to control preference (Figure 2, Figure 3).

$$
\text { growth rate }=\frac{\text { Final weight mini-colony }- \text { Initial weight mini-colony }}{\text { Initial weight mini-colony }} * 100
$$

To estimate the long-term nutritional potential of the sprouts, the growth rate of the mini-colonies was calculated. At the end of the evaluation period, the data were adjusted by means of a regression equation in order to determine the slope of the growth curve and the growth curve of the mini-colony (g/week) as defined in [19], [20].

\section{Estatistical analysis}

The results of germ load, growth percentage and growth speed of the mini-colonies were analyzed with the statistical software $\mathrm{R}$ version 2017. For the hypothesis test, a variance analysis (ANOVA) and the multiple range test $(\mathrm{P}=0.05)$ were performed to determine significant differences between treatments.
Partial rejection response to quinoa may also result from the presence of primary or secondary metabolites and antibacterial and antifungal agents present in quinoa sprouts [21]. Some studies show the antifungal potential of quinoa against Botrytis cinerea using the extraction of saponins extracted from seeds on conidial germination and mycelium growth [22]. This same metabolite has been used for the control of Candida albicans [23]. Given the sensitivity of these insects, it is feasible that these have been detected by the ants generating some type of rejection, that in this study is evidenced in the weight of loaded towards the chamber of the minicolonies. 


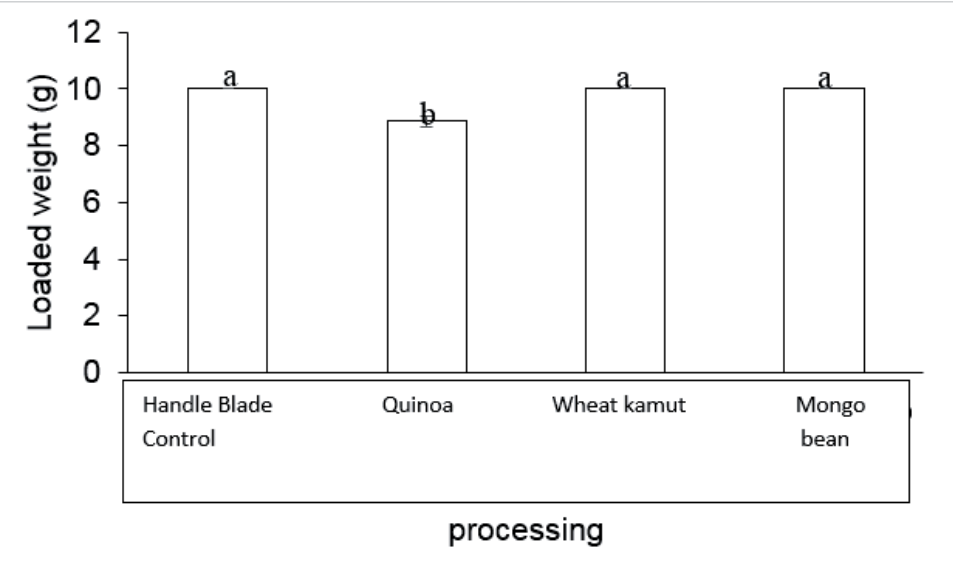

Figure 2. Growth rate of the mini-colonies (ants+fungus) of each of the wheat sprouts kamut (triticum turgidum), quinoa (chenopodium quinoa) and mungo bean (vigna radiata) and their control. different letters represent statistically significant differences.

Mounting

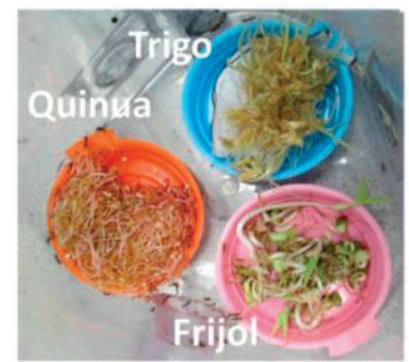

Figure 3. preliminary evaluation of total load of wheat germinates kamut (triticum turgidum), quinua (chenopodium quinoa) and frijol mungo (vigna radiata) and control (handle sheets mangifera indicates) loaded by cutting ants atta cephalotes after 24 hours.
Another factor that may be associated with preference is nutritional composition. Some authors suggest that worker forage ants obtain only $5 \%$ to $9 \%$ of the mycelium nutritional requirements of the fungus, since during foraging they ingest plant sap [24], [25], so that food selectivity may be associated with preferred ant compounds such as polysaccharides. In studies carried out with Atta sexdens cutter ants, it is reported that ants had a better preference for diets with high glucose concentration, generating a higher survival [26]. Some authors report carbohydrate percentages of $10 \%$ and $6 \%$ for kamut wheat and mung bean respectively. Other studies also indicate values of $4.1 \%$ in the form of sucrose in kamut wheat [27], which could generate a differentiating element that would affect not only the preference of ants and the nutritional potential of kamut wheat that would later be reflected in the growth of mini-colonies. Differences in glucose content between sprouts could be one of the causes of the differences found in this study. some reports show that the vegetable fragments cut by ants serve as available substrate to produce enzymes such as amylases, pectinases, cellulases, biomass converting hemicellulases and sugar compounds that help the growth of symbiont fungus [28], [29].

The studies carried out with Triticum sp. indicate that the germination processes generate decomposition of complex polysaccharides including starch. This results in increased concentrations of reducing sugars, amino acids, and many other molecules of nutritional importance to the developing embryo [30]. From a nutritional point of view, it is possible that the diversity of simple molecules present in kamut wheat have been easily accessible to ants and this has contributed to the preference by increasing their load.

It is important to note that other researchers contradict these studies by indicating that ants obtain food directly from the leaves they forage, but that polysaccharides do not necessarily pass through their mouth filter and therefore do not make a significant part of their diet. In the case of the ants 
Atta cephalotes these nutrients can continue being a factor that determines the preference or rejection, but they would not necessarily correspond to nutrients that are incorporated directly to their feeding. In spite of this, they could still be important for the feeding of colonies to the extent that they can be exploited by the symbiote fungus [31]-[34].

Studies by other authors indicate that ants collect approximately $6 \%$ of their body weight in carbohydrates using Ligustrum ovalofolium leaves as a diet. However, other authors [23], [35] found highervalues of direct use of forage material, reducing to only $9 \%$ the nutritional needs obtained from the fungus. This report contradicts the majority that indicate that the mutualist relationship is so close that nutrients are taken in the totality of the symbiontus fungus Leucoagaricus spp. The carbohydrates of the mung bean have high potential as a nutritional element and an energetic and constitutional source of energetic molecules that could favor their preference for their palatability [22], [23].

\section{Growth of mini-colonies}

In the study, the mini-colonies fed with kamut wheat sprouts and the control obtained the best results with growth rates in the exponential growth stage of 3.78 and $3.71 \mathrm{~g} /$ week respectively (Table I), which allowed reaching values of $25 \pm 4 \mathrm{~g}$ and 26 $\pm 2 \mathrm{~g}$ and respectively for the sixth week. Kamut wheat presented the highest growth values reaching percentages of $36 \%$, even surpassing the control with values of $33 \%$.

In the case of the mung bean the growth rate was 1.07 $\mathrm{g} /$ week. For this germinated one stage of adaptation was presented that delayed the growth of the minicolonies reaching values of $7 \pm 3 \mathrm{~g}$ for the fourth week, values lower than the control you obtained for this time pesos of $17 \pm 3 \mathrm{~g}$ (Figure 4).

Table I. Growth rate of the mini-colonies (ants+fungus) of each of the wheat sprouts kamut (triticum turgidum), quinoa (chenopodium quinoa) and mungo bean (vigna radiata) and their control. different letters represent statistically significant differences.

\begin{tabular}{|c|c|}
\hline Processing & Speed (g/week) \\
\hline Control (Handle blades) & $3.78^{\mathrm{a}}$ \\
\hline Wheat kanut (Triticum turgidum), & $3.71^{\mathrm{a}}$ \\
\hline Mungo meat (Vigna radiata) & $1.07^{\mathrm{b}}$ \\
\hline Quinoa (Chenopodium quinoa) & $1.4^{\mathrm{b}}$ \\
\hline
\end{tabular}

In the case of quinoa sprouts, there was a decrease in growth rate, reaching $1 \mathrm{~g} /$ week (Table I) and low increase in the weight of the fungus of the minicolonies (Figure 4). In quinoa the production of primary or secondary metabolites is reported [36] and the presence of antibacterial and antifungal agents that would affect the growth and development of the symbiote fungus and with it the survival of the mini-colonies, which would help to explain this low growth response.

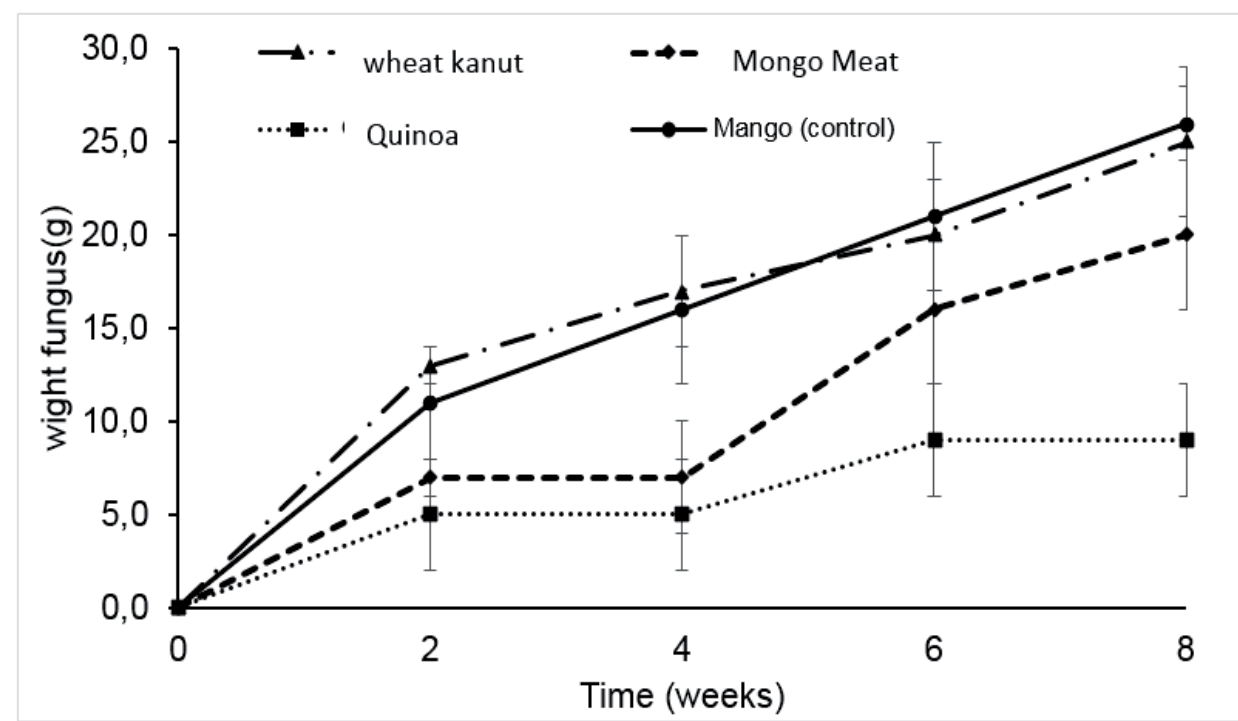

Figura 4. Kinetics of the weight of mini-colonias (mushroom+ants) foods with wheat germinates kamut (triticum turgidum), quinua (chenopodium quinoa) and mungo bean (vigna radiata) and the control of mango sheets (mangifera indica) for 8 weeks. 
As Hidalgo et al., [37] indicate, grains of mature kamut wheat contain many enzymes such as amylases, proteases, oxidases and lipases that exert essential and specific functions during the early stages of sprouting that aid the development of the seedlings and that influence their quality and nutritional properties of the germinate. In this study, these authors also report that amylases are of great importance in pseudocereals because they catalyze the degradation of starch, considered the basis of most food processing pathways. Amylases allow the formation of linear and branched oligosaccharides, maltotriose, glucose and maltose that could have been an easily accessible food source for the symbiont fungus and ants. These transformation processes would therefore facilitate the use and increase of the weight of the fungus for the mini-colonies, thus generating the differences found between the sprouts and the growth kinetics that for the kamut wheat in this study was similar to the control $(26 \pm 2 \mathrm{~g})$.

In this study, quinoa sprouts were not suitable for feeding colonies of $\mathrm{A}$. cephalotes cutter ants. In general they were the least preferred, with an initial load of $8.9 \pm 0.2 \mathrm{~g}$ (Figure I), and the lowest increases in the weight of the fungus of the mini-colonies (Figure III) and with growth rates of $1 \mathrm{~g} /$ week (Table I). It is important to highlight that according to some studies, the nutritional power of quinoa begins to decrease after 3 days of germination, being possible that the germination time used in this study (8 days) has affected its nutritional potential [38]. It is also possible that in the germinated quinoa there are primary or secondary metabolites with fungicidal activity that affect the growth of the mini-colonies.

Sprouts of pseudocereal grains with high nutritional potential have become an excellent option to increase nutritional benefits and effects [39]. Kamut wheat, which was the sprouted wheat with the best nutritional potential, generated the highest growths of the fungus $(25.0 \pm 4 \mathrm{~g}$ hasta la octava semana). These results can be supported with the nutritional reports provided by Singh, et al [40] who analyzed the nutritional power of this germinated pseudocereal, where they indicate that sprouting leads to a significant increase in amino acid levels in the proteolytic protein excision process, which increases the level of free amino acids and the solubilization of polypeptides, given the amount of proteins present in the seeds, activities that in general can be the generators of these good results [41]-[43]. When analyzing the growth percentage of the minicolonies, it was evident that after 8 weeks the values were between $8 \%$ and $37 \%$. The kamut wheat sprout was the one that presented the best growth values, reaching values of $37 \%$, surpassing even the control that presented values of $33 \%$ and evidencing the potential of wheat sprouts for the maintenance of colonies under laboratory conditions (Figure 5).

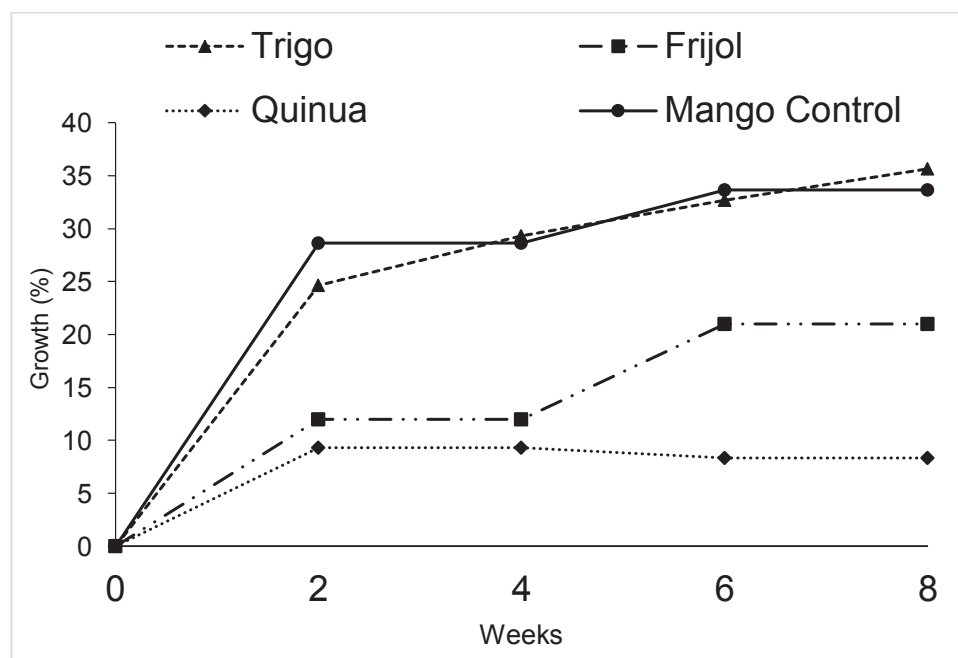

Figure 5. Growth percentage of mini-colonies (ants+fungus) with each of the wheat sprouts kamut (triticum turgidum), quinoa (chenopodium quinoa) and mungo bean (vigna radiata) and control during test time. 
When analyzing the results of the tests of preference of the ants for the germinated ones, it is observed that given the high preference of load, there was a high percentage of growth of the mini-colonies after 8 weeks with a value between $8 \%$ and $37 \%$. It can be inferred that the pseudocereals show a nutritional potential for Atta cephalotes cutter ants, since the operator ants load during the foraging activity or food sources that help the development of the symbiote fungus [3], [4]. These results agree with the nutritional reports of pseudocereals whose main component is starches [44], and are considered as a source of macronutrients and micronutrients including proteins, fiber, fats, minerals and vitamins [45], [46].

Some studies carried out to determine the effects of germination on the nutritional potential of seeds indicate that sprouting improves the vitamin intake of pseudocereals. These buds, after germination, have greater biological activities and more abundant secondary metabolites, since the relevant biosynthetic enzymes are activated during the initial stages of germination, improving nutritional and medicinal qualities [47]. Según Andreas (2017), mung bean sprouts stand out for having a high concentration of vitamin $\mathrm{C}$, ascorbic acid, and high antioxidant activity compared to ripe grains [48]. Likewise, mung bean seed is rich in essential amino acids such as leucine, isoleucine and valine. However, other authors contradict this idea, since these sprouts can present low levels of proteins and minerals, due to the high amount of water and other biochemical processes [48].

Germination significantly reduces levels of sugars and reducing starches and in addition, raffinose and stachyose are completely eliminated during germination. The decrease in sucrose in the later stages of sprouting may be due to a lack of raffinose, resulting in the hydrolysis of sucrose for energy supply. The nutritional composition in the structuring elements such as the amino acids of the mung bean, is evidenced in the growth of the colonies with the best growth of the colony $(20.0 \pm 4 \mathrm{~g}$ en la semana 8$)$, which postulates it as an alternative food for fodder ants of the genus Atta. Other carbohydrates such as fructose and glucose increase drastically in the germinative material, especially in the initial germination phase [40] [46]. Although the mung bean did not generate the best results, the carbohydrates in it have high nutritional and energetic potential that contribute to the growth of the mini-colonies [41], [42]. A wide range of metabolites are reported for mongo beans, including different phenolic acids such as gentístico acid, cinnamic acid and p-hydroxybenzoic acid, other acids such as caffeic acid, ferulic acid, shikimic acid, gallic acid, chlorogenic acid and coumarin and catechin, all of which may together be factors that affect the symbiotic relationship between the fungus and the ant, generating negative effects such as those evidenced in the first weeks of study [49].

When analyzing protein contents, studies comparing cereals and pseudocereals indicate that both present similar amounts of crude protein. In the case of quinoa, significant percentage of peptides are reported with about 35\% [50], however this content was not a generator of fungus growth in the minicolony.

It is important to determine other factors such as the concentration of tannins present in cereals such as wheat and some pseudocereals such as quinoa. This type of compounds affect the functionality of many molecules and generate a lower digestibility of most nutrients, especially proteins [51]. The presence of tannins may help explain the negative results found in this study.

The highest growth rates of the symbiote fungus Leucoagaricus gongylophorus were presented by the kamut wheat sprouts and the exponential phase control with values of 3.19 and $3.73 \mathrm{~g} /$ week respectively, compared with mung and quinoa beans with a speed of $1 \mathrm{~g} /$ week (Table I). The growth rates in the different treatments evaluated presented significant differences between the control and kamut wheat and mung bean with quinoa $(\mathrm{P}<0.004)$. To understand the differences between these pseudocereals, we could resort to studies in which it is indicated that although starch is stored in semi-crystalline structures called starch granules, which vary in size, shape and amylose relationship: amylopectin [52] which affects the technofunctional properties of its food derivatives [53], [54] and 
possibly affects the nutritional potential of sprouts for ants.

Despite the nutritional reports of mung beans, the results of their nutritional potential for the minicolonies were not the best in the eighth week of study and growth rates reached lower values with $1 \mathrm{~g} /$ week, (Table I). For this germinated one stage of adaptation of the mini-colonies was presented that delayed its growth the first month of study as a consequence of the change of feeding only an increase was obtained for the week 8 with values of $20 \pm 4$ g (Figura IV), comparado con el control 26 $\pm 2 \mathrm{~g}$ ). It is possible that the antimicrobial activity reported for this pseudocereal would have affected the growth of the mini-colony [55]. However, this negative effect was surpassed for the second month of the trial, where growth rates were improved by demonstrating the ants> capacity to adapt.

\section{Conclusions}

This increase in speed supports the nutritional potential of this pseudocereal which is known because both its seeds and shoots are a rich source of nutrients [15]. However, the effect of the high content of flavonoids, phenolic acids, organic acids and lipids flavone, isoflavone, flavonoids and isoflavonoids [18], [56] and the wide variety of organic acids, including phosphoric acid and citric acid, and lipids, including tocophore [57] could have effects not so clear given the mutualism ant - fungus. In the medium term this pseudocereal could be included to diversify the feeding of Atta cephalotes colonies under laboratory conditions, however, quantities and proportions should be evaluated.

The growth rate (g/week) was the differentiating variable for the evaluation of sprouts, where kamut wheat had values 3 times higher than mungo bean and quinoa. Kamut wheat contains $16 \%$ protein, having a higher nutritional value than mung bean which has approximately $3 \%$ [58]. The results show that the evaluation of the kinetics of the weight of the colonies is useful to evaluate ants' capacity to use the nutrients present in their diets.

This study concludes that kamut wheat sprouts (Triticum turgidum) is the sprout with the best potential as a food source for Atta cephalotes cutter ant colonies under laboratory conditions. It is recommended to continue searching for more feeding options that allow to develop food rotation schemes with other carbohydrate-rich sources and to evaluate it in other species of the genus Atta, which are also considered pest insects and are widely used in studies in laboratory conditions.

\section{Acknowledgements}

We are grateful to Colciencias for its economic support that made possible the development of this study, to the center of laboratories and the Vicerectory of Investigations of the University of Medellín, to the University CES and the company Biotropical S.A. We especially want to thank the human team of the group GRINBIO for their technical and professional contribution in the development of the project.

\section{References}

[1] T.M. Della Lucia, L.C., Gandra, y R.N Guedes, "Managing leaf-cutting ants: Peculiarities, trends and challenges", Pest Management Science. vol 70, no 1, pp. 14-23, 2014.

[2] R. Zanetti, J.C. Zanuncio, J.C. Santos, W. da Silva, G. Ribeiro, P.G. Lemes, T. Ribeiro, P.G. Lemes, y W. Paiva da Dilva, "An Overview of integrated management of leaf-cutting ants (Hymenoptera: Formicidae), Brazilian forest plantations", Forests., vol 5, no 1, 439-454, 2014.

[3] J. Montoya-Lerma, C. Giraldo-Echeverri, I. Armbrecht, A. Farji-brener, y Z. Calle, "Leaf-cutting ants revisited: Towards rational management and control", International Journal of Pest Management., vol 58, no 3, pp. 225-247, 2012.

[4] M.A. Nickele, M. R. Pie, W. Reis Filho, S. do Rocio Chiarello Penteado "Formigas cultivadoras de fungos: estado da arte e direcionamento para pesquisas futuras", Pesquisa Florestal Brasileira, vol. 33, no. 73, pp. 53-72, 2013.

[5] R. Escobar, F. García, J. Neita, D. Murillo, S. 
Mena, "Hormigas cortadoras de la tribu Attini en sistemas productivos del departamento del Chocó", Revista Institucional Universidad Tecnológica del Choco, vol.15, pp. 35-45, 2002.

[6] J. Montoya-Lerma, P. Chacon de Ulloa y M.R. Manzano. "Caracterización de nidos de la Hormiga arriera, Atta cephalotes (Hymenoptera: Myrmicinae) en Cali (Colombia)", Revista Colombiana de Entomología, vol. 32, no. 2, pp. 151-158, oct. 2006.

[7] A. Ortiz, G.E. Guzmán, "Las hormigas cortadoras de hojas del Departamento de Antioquia. Medellín", Colombia: 1st ed. Universidad de Antioquia, Universidad Nacional de Colombia, 2007.

[8] E.I. Valderama, C. Giraldo, J. Montoya Lerma, I. Armbrecht, Z. Calle, "Guía para el establecimiento y manejo de colonias artificiales de hormiga arriera Atta cephalotes (Hymenoptera: Myrmicinae)", Boletín del Museo de Entomología de la Universidad del Valle, vol. 7, no.2, pp.7-16, 2006.

[9] R.D.S. Camargo, J.A. Fonseca; J.F. Santos Lopes; L.C Forti "Influência do ambiente no desenvolvimento de colonias iniciais de formigas cortadeiras (Atta sexdens rubropilosa)" Ciencia Rural. Vol. 43, no.8, pp. 1375-1380, 2013.

[10] J. Sosa-Calvo, A. Jesovnik, E. Okonski y T.R. Schultz "Locating, collecting, and maintaining colonies of fungus-farming ants (Hymenoptera: Myrmicinae: Attini)", Sociobiology, vol. 62, no.2, pp. 300-320, 2015.

[11] S.V. Rama Rao, B. Prakash, U. Rajkumar, M. V. L. N. Raju, T. Srilatha, E. P. K. Reddy "Effect of supplementing germinated sprouts of millets on performance, carcass variables, immune and anti-oxidant responses in commercial broiler chickens reared during tropical summer season", Indian Journal of Animal Sciences. Vol 88, no. 6, pp. 740-743, 2018.
[12] O.N., Donkor, L., Stojanovska, P., Ginn, J., Ashton, T., Vasiljevic, "Germinated grains - sources of bioactive compounds" Food Chemistry, 135, 950-959, 2012

[13] F. Boukid, S. Folloni, S. Sforza, E. Vittadini, B. Prandi, "Current Trends in Ancient GrainsBased Foodstuffs: Insights into Nutritional Aspects and Technological Applications". Food Science and Food Safety. Vol 17, no. 1, pp. 123-136, 2017

[14] R. Schoenlechner, S. Siebenhandl, E. Berghofer "Pseudocereals", en Gluten-Free Cereal Product and Beverages. 1a ed, pp. 149-190, Elsevier; New York, NY, USA: 2008.

[15] J. Taylor, J. Awika, "Cereals, Pseudocereals, and Legumes: Sustainable, Nutritious, and Health-Promoting Foods for the 21st Century", Gluten-Free Ancient Grains. 1 ${ }^{\mathrm{a}} \mathrm{ed}$. Woodhead Publishing Limited; Duxford, UK: 2017.

[16] H.M.H. Zhang, H.S. Cai, "Discussion on the study of lipid-lowering by traditional Chinese medicine. Lishizhen", Materials and Medicinal Research, 6:34-35, 1995.

[17] D. Tang, Y. Dong, H. Ren, Li Li, C.HE. "A review of phytochemistry, metabolite changes, and medicinal uses of the common food mung bean and its sprouts (Vigna radiata)", Chemistry Centra lJournal, vol. 4, no.8, pp. 1-9, 2014.

[18] R. Schoenlechner, S. Siebenhandl, E. Berghofer, "Pseudocereals". En Gluten-Free Cereal Product and Beverages. 2008. pp. 149-190. Elsevier; New York, NY, USA. ISBN: 9780080557762.

[19] S. Martínez, M. G., "Pruebas de crecimiento, síntesis in vitro y caracterización de 10 cepas de hongos ectomicorrizógenos". Tesis de maestría, Facultad de Ciencias, Universidad Nacional Autónoma de México, México, D. F. 1992.

[20] A. Vázquez-García, G. Santiago-Martínez 
y A. Estrada-Torres. "Influencia del $\mathrm{pH}$ en el crecimiento de quince cepas de hongos ectomicorrizógenos". Anales del Instituto de Biología, Universidad Nacional Autónoma de México. Serie Botánica vol.73, pp.1-15, 2002.

[21] M. Sundaram, K. Sivakumar, Karthikeyan, A. Bhuvaneshwari, Aishwarya.G, S.Thirumalai and M.Pennarasi. "Studies on in vitro Antibacterial, Antifungal property and antioxidant potency of Murraya paniculata", Pakistan Journal of Nutrition, vol. 10, no. 10, 925-929, 2011.

[22] Stuardo, M., San Martín, R., "Antifungal properties of quinoa (Chenopodium quinoa Willd) alkali treated saponins against Botrytis cinereal", Industrial Crops and Products, vol. 27, 296-302, 2008.

[23] Woldemichael, G., Wink, M., "Identification and biological activities of triterpenoid saponins from Chenopodium quinoa", Journal Agricultural Food Chemistry, vol. 49, $2327-$ 2332, 2001.

[24] Littledyke, M., Cherrett, J.M., "Direct ingestion of plant sap from cut leaves by the leaf-cutting ants Atta cephalotes (L.) and Acromyrmex octospinosus (Reich) (Formicidae, Attini)", Bulletin of Entomological Research. vol. 66, 205-217, 1976.

[25] Quinlan, R.J., Cherrett, J.M., "The role of fungus in the diet of the leaf-cutting ant Atta cephalotes (L.).", Ecological Entomological. vol. 4, 151-160, 1979

[26] A. Silva, M. Bacci, C. Gomes de Siqueira, O. Correa Bueno, F. C. Pagnocca, M. J. Aparecida Hebling. "Survival of Atta sexdens workers on different food sources", Journal of Insect Physiology, vol. 49, 307-313, 2003

[27] Nutritional Value. Wheat, sprouted. Copyright 2017 NutritionValue.org., dic, 2017. [Online]. Disponible en: https://www.nutritionvalue.org/
[28] Lange, L; Grell, M.N, “The prominent role of fungi and fungal enzymes in the ant-fungus biomass conversion symbiosis", Applied Microbiology and Biothecnology, vol. 98, 4839-4851, nov, 2014. DOI 10.1007/s00253014-5708-5

[29] Silva, A; Bacci Jr, M; Pagnocca, F.C; Bueno ,O.C; Hebling, M.J.A" Production of Polysaccharidases in Different Carbon Sources by Leucoagaricus gongylophorus Mçller (Singer), the Symbiotic Fungus of the LeafCutting Ant Atta sexdens Linnaeus" Curent Microbiology.Vol53 68-71.2006.

[30] P.V., Hung, T., Maeda, S., Yamamoto, N., Morita, "Effects of germination on nutritional composition of waxy wheat", Journal of the Science of Food and Agriculture, 92, 667-672, 2012.

[31] R.J., Quinlan, J.M., Cherrett, "Studies on the role of the infrabucal pocket of the leaf-cutting ant Acromyrmex octospinosus (Reich) (Hym., Formicidae)", Insects Sociaux, vol. 25, 237 295, 1978

[32] M.M., Martin, R.M., Carman, J.G., MacConnel, "Nutrients derived from the fungus cultured by the fungus-growing ant Atta colombica tonsipes", Annals of the Entomological Society of America, vol, 62, 11-13, 1969

[33] C.G., Siqueira, M. Jr., Bacci, F.C., Pagnocca, O.A., Bueno, M.J.A., Hebling, "Asimilation of vegetal cell wall polysaccharide by the symbiotic fungus of the leaf-cutting ant Atta sexdens rubropilosa", Applied and Environmental Microbiology, vol. 64, 48204822, 1998.

[34] M. Jr., Bacci, M.M., Anversa, F.C., Pagnocca, "Cellulose degradation by Leucocoprinus gongylophorus, the fungus cultured by the leafcutting ant Atta sexdens rubropilosa", Antonie van Leeuwenhoek International Journal of General and Molecular Microbiology, vol, 67, 385-386, 1995 
[35] M., Bass, J.M. Cherrett, "Fungal hyphae as a source of nutrients for the leaf- cutting ant Atta sexdens", Physiological Entomology, vol 20, $1-6,1995$

[36] M. Sundaram, K. Sivakumar, Karthikeyan, A. Bhuvaneshwari, Aishwarya.G, S.Thirumalai and M.Pennarasi. "Studies on in vitro Antibacterial, Antifungal property and antioxidant potency of Murraya paniculata". Pakistan Journal of Nutrition, vol 10, no. 10, 925-929, 2011.

[37] A. Hidalgo, M. Brusco, L. Plizzari, A. Brandolini. "Polyphenol oxidase, alphaamylase and beta-amylase activities of Triticum monococcum, Triticum turgidum and Triticum aestivum: A two-year study" Journal of Cereal Science. vol. 58, no.1, pp 51-58, 2013.

[38] D.C. Chaparro Rojas, R.Y. Pismag Portilla, A. Elizalde Correa, N.J. Vivas Quila, y C.A. Erazo Caicedo. "Effect of the germination on the protein content and digestibility in amaranth, quinua, soy bean and guandul seeds". Revista Biotecnología en el Sector Agropecuario y Agroindustrial, vol 8, no. 1, 35-42, 2010.

[39] K., Nelson, L., Stojanovska, T., Vasiljevic, M., Mathai, "Germinated grains: a superior whole grain functional food?" Canadian Journal of Physiology and Pharmacology, vol 91, 429441, 2013.

[40] A.K., Singh, J., Rehal, A., Kaur, G., Jyot, "Enhancement of attributes of cereals by germination and fermentation: a review", Critical Reviews in Food Science and Nutrition, 55, 1575-1589, 2015

[41] A. Mubarak, "Nutritional composition and antinutritional factors of mung bean seeds (Phaseolus aureus) as affected by some home traditional processes", Food Chemestry, vol 89, 489-495, 2005.

[42] D. Tang, Y. Dong, H. Ren, L, Li, C. He, “A review of phytochemistry, metabolite changes, and medicinal uses of the common food mung bean and its sprouts (Vigna radiata)",
Chemistry Central Journal, vol 8, 4-10, 2013

[43] E-SA. Abdel-Rahman, F.A., El-Fishawy, M.A. El-Geddawy, T., Kurz, M.N. El-Rify, "The changes in the lipid composition of mung bean seeds as affected by processing methods". International Journal Food Engineering, vol 3, no. 5, 1-10. 2007

[44] R.F. Tester, J. Karkalas, X. Qi "StarchComposition, fine structure and architecture", Journal of Cereal Science. vol 39, no. 2, 151165, 2004.

[45] C.M.Haros, R.Schoenlechner"Pseudocereals", Chemistry and Technology. 1a ed. Wiley Blackwell; Chichester, UK: 2017. 256 p.

[46] F. Janssen, A. Pauly, I. Rombouts, K.J.A. Jansens, L.J. Deleu, J.A. Delcour "Proteins of amaranth (Amaranthus spp.), buckwheat (Fagopyrum spp.), and quinoa (Chenopodium spp.): A food science and technology perspective", Comprehensive Reviews Food Science and Food Safety. Vol. 16, 39-58, 2017.

[47] T, El-Adawy, E, Rahma, A. El-Bedawey, A. ElBeltagy, "Nutritional potential and functional properties of germinated mung bean, pea and lentil seeds", Plant Foods Human Nutrition, vol, 58, 1-13, 2003,

[48] W. E., Andreas, C. Ching-Huan, Y. MiaoRong, Y. Ray-Yu. "Nutritional composition of mungbean and soybean sprouts compared to their adult growth stage". Food Chemistry, vol 237, 15-22, 2017

[49] H.P., Singh, S., Kaur, D.R., Batish, R.K., Kohli, "Caffeic acid inhibits in vitro rooting in mung bean [Vigna radiata (L.) wilczek] hypocotyls by inducing oxidative stress", Plant Growth Regulators, vol 57, 21-30, 2009.

[50] M. Montemurroa, E Pontonioa, M. Gobbettib, C. Giuseppe Rizzelloa, "Investigation of the nutritional, functional and technological effects of the sourdough fermentation of sprouted flours", International Journal of 
Food Microbiology, in press, 2017

[51] R.Y., Khattab, S.D., Arntfield, "Nutritional quality of legume seeds as affected by some physical treatments 2. Antinutritional factors". LWT- Food Science and Technology, vol, 42, 1113-1118, 2009.

[52] K.J. Steadman, M.S. Burgoon, B.A. Lewis, S.E. Edwardson, R.L. ObendorfR. "Buckwheat seed milling fractions: Description, macronutrient composition and dietary fibre" Journal of cereal Science, vol 33, no 3, pp.271-278, 2001.

[53] M. Schirmer, A. Höchstötter, M. Jekle, E. Arendt, T. Becker "Physicochemical and morphological characterization of different starches with variable amylose/amylopectin ratio", Food Hydrocolloids, vol. 32, no. 1, 5263, 2013.

[54] S.W. Horstmann, M.C.E. Belz, M. Heitmann, E. Zannini, E.K. Arendt "Fundamental study on the impact of gluten-free starches on the quality of gluten-free model breads", Foods, vol 5, no.2, pp1-12, 2016.

[55] R. Randhir, Y-T Lin, K Shetty. "Stimulation of phenolics, antioxidant and antimicrobial activities in dark germinated mung bean sprouts in response to peptide and phytochemical elicitors". Process Biochemical, 2004, vol, 39: 637-646.

[56] S. Wang, B. Shao, H. Fu, P. Rao. "Isolation of a thermo-stable legume chitinase and study on the antifungal activity". Applied Microbiology and Biotechnology, vol. 85 no.2, pp. 313-321, 2009.

[57] D.J. Bowles. "Defense-related proteins in higher plants", Annual Rev Biochemistry, vol, 59, no. 1, 873-907, 1990.

[58] Nutritional Value. Mung beans, raw, sprouted, mature seeds. Copyright 2018 NutritionValue. org, dic, 2017. [Online]. Disponible en: https:// www.nutritionvalue.org/ [Accessed: 16- dec2017]. 